\title{
Behavioural Investor Individual in Capital Stock Indonesia: DISC Personality, Market and Accounting Information
}

\author{
Elizabeth Lucky Maretha Sitinjak ${ }^{1 *}$, Kristiana Haryanti ${ }^{2}$, Widuri Kurniasari ${ }^{3}$, and Yohanes
} Wisnu Djati Sasmito ${ }^{3}$

${ }^{1}$ Accounting Department, Soegijapranata Chatolic University, Indonesia

${ }^{2}$ Psychology Department, Soegijapranata Chatolic University, Indonesia

${ }^{3}$ Management Department, Soegijapranata Chatolic University, Indonesia

\begin{tabular}{|c|c|}
\hline ARTICLE INFO & ABSTRACT \\
\hline $\begin{array}{l}\text { Keywords: } \\
\text { AHP } \\
\text { Profitability Ratio } \\
\text { Market Ratio } \\
\text { Moving Average } \\
\text { Precisionist }\end{array}$ & $\begin{array}{l}\text { Every individual investor has an error in making a decision to buy or sell } \\
\text { shares. Mistakes in making predictions can be minimized by } \\
\text { understanding his personality and the steps taken in getting better } \\
\text { returns. This study uses Analytical Hierarchy Process (AHP), secondary } \\
\text { data, Focus Group Discussion (FGD), and stock simulations } \\
\text { emphasizing the decision-making process when buying and selling } \\
\text { shares. The initial AHP model gives the results of the target shares } \\
\text { purchased, accounting information selected Price Book Value (PBV) } \\
\text { that is undervalued, Return on Assets (ROA) around } 10-20 \text { percent, } \\
\text { Return in Equity (ROE) around 20-40 percent, type of ownership } \\
\text { Indonesian SOEs selected stocks for the long term, while short-term tend } \\
\text { to be private, and use technical analysis by looking at the upward trend } \\
\text { that is using moving average indicators, MA5 above MA20. As a result, } \\
\text { individual stock investors who have only become stock investors for less } \\
\text { than } 1 \text { year have stock returns of around } 2-4 \text { percent, already become } \\
\text { investors, } 1-3 \text { years will get a return of around } 10 \text { percent, stock returns } \\
\text { will rise again, long-term investments will be made. around } 20 \text { percent. } \\
\text { The risk for short-term investment will be greater than the long-term } \\
\text { investment. The DISC personality that fits this stage is precisionist. }\end{array}$ \\
\hline
\end{tabular}

\section{Introduction}

Humans are having the highest nature in the universe. Humans in science are often referred to as homo economicus, not emotional and fully rational. But not entirely so, humans are homo sapiens who have ambiguous emotions, such as anger, hatred, guilt, shame, pride, regret, joy, sadness, jealousy, greed, fear, and love. This makes the discipline of economics with psychology inseparable, the two disciplines form the cognitive psychology model and the economic model is far more realistic (Turan \& Latifi, 2013). This research is also the case, combining investor personality with information that is often given to investors, both investors are still learning to investors who are already proficient.

The behaviour of stock investors is unique enough to continue to be traced. There are two major groups of behaviour that researchers have observed so far. Groups that tend to look for a lot of accounting and company management information are interested in stock investors, and groups that tend to look for the right stock momentum to enter or buy shares of the company. These two groups are often called rational investors and irrational investors. Rational investors often use fundamental analysis tools rather than technical analysis,

* Corresponding author E-mail address: lucky@unika.ac.id 
whereas irrational investors tend to use technical analysis tools rather than fundamental analysis (Natapura, 2009).

The Nobel Prize in Economics (October 2013) also recognizes the existence of these two different poles. Pole Market Efficient Theory (Eugene F. Fama) and Pole Market Theory Not Efficient by financial behaviour (Robert J. Shiller). Market-efficient theory emphasizes information has power (information of the past, present and future) in making a decision, if the market provides information, then the market reacts quickly (a strong form of efficiency). While Inefficient Market Theory, there is an information bias for individual investors, because there are psychological aspects in decision making. Bias behaviour of individual investors such as overconfidence, over-optimism, representativeness, conservatism, availability of bias, mental accounting, and regret aversion (Byrne \& Brooks, 2008).

Previous research that has been done by researchers relating to the behaviour of capital market investors is, stock investors are still considering the annual financial statements issued by issuers at the end of March or early April as part of decision making (Maretha, 2013). The annual financial statements are still relevant as part of the decision making of these stock investors supported by Natapura (2009), Kadariya (2012), Maretha, et all. (2016), in contrast to other studies which say financial statements are not part of decision making in investing in the capital market (Septyanto, 2013). Septyanto (2013) said the benefits of financial information were not significant to revise investor beliefs in buying or selling company shares. The factors that most influence it is information that is shared by friends, colleagues or family and not directly from the company's performance. This is often called herding behaviour (Banerjee, 2008; Baddeley, 2012).

The two groups and the two poles mentioned above have made researchers develop investor behaviour towards personalities, company life cycles, and company valuations that have been listed on the Indonesia Stock Exchange (IDX). Researchers see that there are three large groups of companies listed on the IDX, namely BUMN (4.8\%), BUMD companies $(0.6 \%)$ and Private companies (94.7\%). These three groups of companies have different characteristics in giving corporate actions. BUMN and BUMD companies often give part of their profits to investors in the form of dividends. However, the BUMD sometimes gives a slightly greater dividend than a BUMN. This is due to the fact that most of the shares owned by BUMD companies are held by investors who are in the area, while the majority of BUMNs are owned throughout the archipelago.

Three major groups of companies listed on the IDX will first be mapped to the company's life cycle. Mapping starts from a new company listed on the IDX or an Initial Public Offering (IPO) entering the start-up stage, then the company enters the growth stage, after which the company enters the maturity stage, and also maps the companies that decline (decline). Mapping the company is done by looking at the company's cash flow over the past three years. After mapping the company's life cycle, researchers will enter into the valuation of the company's valuation or the valuation of its assets. The purpose of researchers doing this, researchers will create a model of stock investor behaviour that shows the two different poles. Mapping data is the basis for asking individual investors the decision to make a purchase, sale, or hold.

\section{Materials and Methods}

\subsection{Market Information}

Lipe (1998) uses accounting information and market information in risk assessment and making investment decisions. His experimental study examined the risk considerations and decisions of individual investors to invest influenced by variables (yield variance and yield covariance with market yields) and accounting risk measurement. The accounting data used 
in his study are in the form of current ratios, solvency ratios, and profitability ratios over the past five years, as well as market data in the form of market indexes for the past five years. The results of his study said variance, covariance, yield expectations have an effect on investment decisions and risk assessment.

This study provides an overview of investment strategies that are often used by scholars is a top down analysis. Therefore, researchers provide a macroeconomic picture that directly impacts the capital market to individual investors. Macroeconomic data shown are GDP, inflation, and interest rate. Then, given industry information that can be seen virtually with technical analysis. Furthermore, the performance of companies that want to be purchased such as Price Book Value (PBV), Return on Assets (ROA), Return on Equity (ROE), and undervalues or overvalues of Price Earnings Ratio (PER).

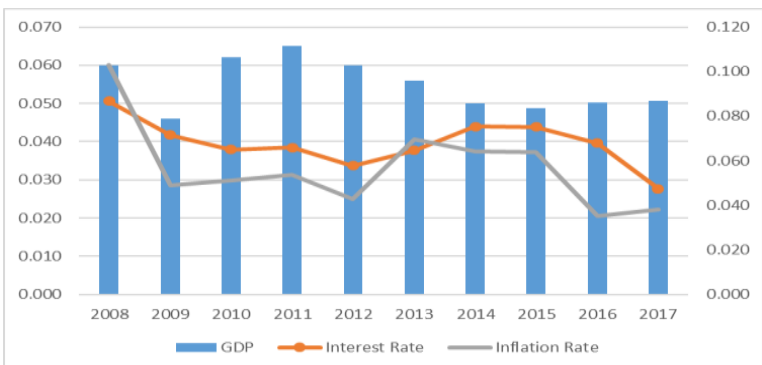

Figure 1. Market Information (Source: www.bi.go.id; Data processed ,2019)

Figure 1 shows that Indonesia's GDP growth in the last 3 years has been quite stable around 5.21-5.27 (www.bi.go.id), it can also be seen that low inflation is controlled by low interest rates. The industries most at risk are the banking industry, and industries that are very resistant to crises are the food and leverage industry. Meanwhile, other industries have their own business cycles. Currently the industry that is in a growth cycle is the infrastructure industry. This is due to demand and development in every region of Indonesia, from the tip of Sabang to Marauke (Papua).

\subsection{Accounting Information}

Behavioural accounting research emerged in the 1950s to the present. The focus of his research, investigates how users of accounting information make decisions and what information they need. Research related to capital markets and accounting often uses Kothari (2001) which says there is a relationship between capital markets and financial statements. The main sources of empirical research demand in the capital market in accounting are fundamental analysis, valuation, and market efficiency testing. Fundamental analysis using financial ratios to predict future profits, using the time-series forecasting method and forecasting analysis. As a result, ratios can predict revenue growth. The size of existing ratios also predicts trading strategies by exploiting information about revenue growth. This revenue prediction signal also produces abnormal returns. Then the inefficient market also requires accounting information in the company's financial statements.

Lawrence and Kercsmar (1999) research on the process of tracking information selection activities by decision makers is used to assess the importance of accounting-based, marketbased, and analyst-based information in investment decisions. The steps taken are through a number of questions, such as: What information is considered for general information? How to select useful information? What judgment or decision was made? 
Table 1.

\begin{tabular}{|c|c|c|c|c|c|c|c|c|c|c|}
\hline \multirow{2}{*}{$\begin{array}{l}\text { BUMN/ } \\
\text { BUMMD }\end{array}$} & \multicolumn{2}{|c|}{2013} & \multicolumn{2}{|c|}{2014} & \multicolumn{2}{|c|}{2015} & \multicolumn{2}{|c|}{2016} & \multicolumn{2}{|c|}{2017} \\
\hline & PROFIT & FCF & PROFIT & FCF & PROFIT & FCF & PROFIT & FCF & PROFIT & FCF \\
\hline ADHI & 0.02479 & -0.01837 & -0.00841 & 0.09121 & 0.0132 & -0.35025 & -0.00894 & 0.04607 & 0.01005 & 0.00893 \\
\hline ANTM & -0.13107 & 0.03114 & -0.05421 & 0.03295 & -0.03019 & -0.36545 & 0.04960 & 0.28846 & 0.00239 & 0.04081 \\
\hline GIAA & -0.03926 & -0.05732 & -0.14810 & -0.0843 & 0.14829 & 0.03364 & -0.02074 & 0.10313 & -0.05992 & 0.06436 \\
\hline INAF & -0.08128 & 0.22858 & 0.04279 & -0.12385 & 0.00433 & -0.00688 & -0.01560 & 0.01248 & -0.02093 & 0.01874 \\
\hline JSMR & & -0.17436 & -0.00 & & & 0.093 & 0.01318 & & 00543 & \\
\hline KAEF & 0.00476 & 0.01168 & 0.00845 & -0.06649 & 0.00554 & 0.12701 & 0.00576 & -0.21096 & 0.01303 & 0.00605 \\
\hline KRAS & 0.00094 & -0.12713 & -0.06658 & 0.07347 & -0.07897 & -0.55240 & 0.04065 & 0.44454 & 0.02385 & -0.09286 \\
\hline PGAS & 0.05411 & -0.13303 & -0.02998 & -0.21765 & -0.04843 & 0.01832 & -0.01574 & & -0.02335 & 0.01918 \\
\hline PJAA & 0.00513 & 0.16232 & 0.01636 & 0.0336 & 0.01938 & 0.00170 & -0.04330 & -0.00062 & 0.01864 & -0.02777 \\
\hline PTBA & -0.08289 & 0.14362 & 0.01412 & $-0.2748 \varepsilon$ & 0.00121 & 0.07388 & -0.00075 & -0.04179 & 0.13581 & 0.00798 \\
\hline PTPP & 0.01299 & -0.01955 & 0.00897 & 0.01006 & 0.02146 & -0.12674 & 0.01599 & -0.19972 & 0.01833 & 0.04735 \\
\hline SMBR & 0.01141 & -1.10864 & 0.00596 & 0.44155 & 0.00883 & 0.00781 & -0.02909 & -0.24292 & -0.02574 & 0.14806 \\
\hline SMGR & & 0.07153 & 0.00693 & 0.00767 & -0.03036 & 0.00503 & 0.00025 & -0.06725 & -0.05635 & \\
\hline TINS & 0.01362 & 0.00738 & 0.01558 & -0.08718 & -0.05500 & 0.01458 & 0.01621 & 0.04848 & 0.02623 & -0.18600 \\
\hline TLKM & 0.6 & -0.03716 & 0.00903 & & & -0.069 & & & & \\
\hline WIKA & & & 0.01004 & & & 0.04157 & 0.02266 & -0.28037 & 0.00672 & 0.15396 \\
\hline & & & & & & & & & & \\
\hline
\end{tabular}

\begin{tabular}{|c|c|c|c|}
\hline $\mathbf{2}$ & $\mathbf{3} 13$ & $\mathbf{2 0 1 5}$ & $\mathbf{2 0 1 6}$ \\
\hline \multicolumn{3}{|c|}{ ASSET TOTAL } \\
\hline $23.49 \%$ & $7.59 \%$ & $60.26 \%$ & $19.89 \%$ \\
\hline $10.94 \%$ & $0.82 \%$ & $37.71 \%$ & $-1.24 \%$ \\
\hline $25.59 \%$ & $20.30 \%$ & $20.25 \%$ & $12.41 \%$ \\
\hline $8.91 \%$ & $-3.57 \%$ & $22.86 \%$ & $-9.92 \%$ \\
\hline $14.60 \%$ & $12.31 \%$ & $15.28 \%$ & $45.68 \%$ \\
\hline $19.05 \%$ & $20.08 \%$ & $9.03 \%$ & $42.53 \%$ \\
\hline $17.07 \%$ & $11.45 \%$ & $58.00 \%$ & $3.57 \%$ \\
\hline $40.73 \%$ & $45.39 \%$ & $15.88 \%$ & $2.48 \%$ \\
\hline $10.00 \%$ & $10.66 \%$ & $7.68 \%$ & $20.39 \%$ \\
\hline$-8.26 \%$ & $26.85 \%$ & $14.06 \%$ & $9.96 \%$ \\
\hline $45.20 \%$ & $17.69 \%$ & $30.91 \%$ & $63.28 \%$ \\
\hline $126.22 \%$ & $7.93 \%$ & $11.70 \%$ & $33.66 \%$ \\
\hline $15.85 \%$ & $11.49 \%$ & $11.13 \%$ & $15.92 \%$ \\
\hline $28.60 \%$ & $23.71 \%$ & $-4.85 \%$ & $2.90 \%$ \\
\hline $14.89 \%$ & $10.12 \%$ & $17.94 \%$ & $8.09 \%$ \\
\hline $15.07 \%$ & $26.36 \%$ & $23.17 \%$ & $58.64 \%$ \\
\hline $5.04 \%$ & $42.71 \%$ & $141.66 \%$ & $102.66 \%$ \\
\hline
\end{tabular}

Source: Data processed (2019)

What information is considered depends on each individual investor. It's just that the information discussed by investors is three points, namely profit or profit, free cash flow of the company, and the total assets that the company. Table 1 above contains BUMN and BUMD companies that are included in the LQ-45 and IDX BUMN 20 Index showing profit and free cash flow (FCF) related to total assets that are growing each year. BUMN that has a large growth in assets related to the infrastructure industry. This is also supported by a large FCF as well, so accounting information is very relevant to be considered when making a buysell-or hold stock investment decision.

\subsection{Approach}

This research has three stages, namely filling the DICS personality, simulating buying and selling and holding of shares, and conducting FGDs so that it can multiply the behaviour of individual investors in the city of Semarang, Indonesia. Besides that, the researcher mapped key words when the FGD became a quantitative variable by distributing investor behaviour questionnaires to individual investors who took stock simulations for 30 minutes.

Each question was also adjusted to the questions posed during the FGD. A FGD is also recorded when recording a discussion about the behaviour of both the investor being observed or the individual investor himself, then the voice recording is done verbatim so that keywords and keyword frequencies appear in each FGD. The next stage is an Analytical Hierarchy Process (AHP) assessment by means of each criterion (table 1).

\subsection{DISC Personality}

Some of the measurements of personality one of the measuring tools that are simple in the process, interesting, have good validity and reliability and are quite easy to learn are DISC (Dominance, Influence, Steadiness, Compliance). This DISC test provides a description and character of a person's personality that can predict future behavioural tendencies. This is obtained from evaluating the main personality factors that exist in a person.

DISC provides an advantage in ease of use, because this test only takes a maximum of 15 (fifteen) minutes to complete the twenty-four (24) questions contained therein. This personality test, a person will be confronted with four adjectives in a number and they are asked to choose one word that they think best suits him and one more word that does not suit him best. Expertise interpretation of personality dynamics in this measuring instrument can be seen from the graph is the key to the accuracy of the analysis. When this is available the 
results of interpretation of the work of DISC can be done by using a software automatically so that it will be very easy for interpreters to know the character of one's personality.

Basically, DISC measures a person's personality traits, namely Dominance, Influence, Steadiness, and Compliance, which can show a picture of the tendency of behaviour of an individual. DISC can help understand "why someone does something". Besides that, the dynamics of the dimensions of Dominance, Influencing, Steadiness, and Conscientiousness in each different person form a personal DISC model (style) that can describe each other's behaviour.

\subsection{Focus Discussion Group (FGD)}

The FGD was conducted in two sessions, the first session was at noon around 3:00 PM - 4:00 PM Western Indonesia Time (WIB), while the second session was around 5:00 PM - 6:00 PM WIB. Because during the fasting month FGD, the second session was more than the first session, because it was closed by breaking the fast together. The first FGD results, respondents prefer trading rather than holding for too long. Macro information which is often seen by Dow Jones' condition is only the condition of Indonesian politics, not its Macro information. Therefore, researchers conducted other research models that show macro information having an impact on aquatic information and technical information.

FGD was conducted for 30 minutes. Emotion Bias is the experience of buying shares of BUMN, BUMD and Private having experienced loss aversion, overconfidence, overestimate by using fundamental analysis or technical analysis. Cognition bias is also the same, have you ever experienced the regrets of buying BUMN or BUMD or Private shares. The information obtained is hoax information (cognitive dissonance) that makes the decision incorrect.

Table 1.

\begin{tabular}{|c|c|c|c|c|}
\hline 1 & $\begin{array}{l}\text { Both elements are equally } \\
\text { important }\end{array}$ & \multirow{5}{*}{ Criteria: } & 1 & $\begin{array}{l}\text { The behavior of targeted } \\
\text { investor } \& \text { accuracy }\end{array}$ \\
\hline 3 & $\begin{array}{l}\text { One element is a little bit more } \\
\text { important than the other one }\end{array}$ & & 2 & $\begin{array}{l}\text { Investor behavior, } \\
\text { relationship \& self- } \\
\text { assessment }\end{array}$ \\
\hline 5 & $\begin{array}{l}\text { One element is more important } \\
\text { than the other one }\end{array}$ & & 3 & $\begin{array}{l}\text { Investor Behavior, } \\
\text { Choosing Information \& } \\
\text { Surrounding Environment }\end{array}$ \\
\hline 7 & $\begin{array}{l}\text { One element is far more } \\
\text { important than the other one }\end{array}$ & & 4 & Technical Analysis Behavior \\
\hline 9 & Absolutely more important & & 5 & $\begin{array}{l}\text { Fundamental Analysis } \\
\text { Behavior }\end{array}$ \\
\hline $2,4,6,8$ & $\begin{array}{l}\text { The mean value between two } \\
\text { adjacent opinions }\end{array}$ & & & \\
\hline
\end{tabular}

Source: Saaty (1987); Sitinjak, et al. (2019)

\subsection{Analytical Hierarchy Process (AHP)}

The next stage, AHP test was carried out. This study uses analytical hierarchy process (AHP) for each criterion that is examined. AHP is used to achieve the goal of this research by reducing the behaviour bias of individual investors when buying, selling, or holding shares. AHP is very suitable with the decision-making process that can be made in stages. Each criterion has a different hierarchy for its continuous approach.

The AHP process as a whole has the following stages: (1) Creating a hierarchy model to be questioned; (2) Setting priorities by providing criteria for each level (table 2); (3) Measuring consistency; (4) Evaluating consistency where CR <0.1 (Tabl1 1). After testing with AHP, the results of FGD, AHP and circulating questionnaires, researchers made several models of 
processed data obtained either by filling out questionnaires, interviews, or mapping behaviour based on the age of experience doing stock investment transactions.

Table 2.

Decision Making Model

\begin{tabular}{|c|c|l|l|}
\hline F1 & DM BASE ON TARGET \& ACCURACY \\
\hline 9 & PIP14 & $\begin{array}{l}\text { Individual Investors Trying to Achieve Targets According to } \\
\text { Planning }\end{array}$ \\
\hline 7 & PIP15 & $\begin{array}{l}\text { Individual Investors Trying to Do Precision in Doing the Main } \\
\text { Work }\end{array}$ \\
\hline 5 & PIP13 & $\begin{array}{l}\text { Individual Investors Trying to Have High Accuracy Standards in } \\
\text { The Stock Investment Transaction }\end{array}$ \\
\hline 3 & PIP16 & $\begin{array}{l}\text { Individual Investors Are Trying to Be Comfortable and Liking the } \\
\text { Environment When Less Clearly the Regulations So That Can Be } \\
\text { Flexible }\end{array}$ \\
\hline F2 & DM BASE ON RELATION \& SELF JUGMENT \\
\hline 9 & PIP03 & $\begin{array}{l}\text { Individual investors feel uneasy when making decisions that can } \\
\text { have a negative impact on others }\end{array}$ \\
\hline 5 & PIP02 & $\begin{array}{l}\text { Individual investors feel there is a disadvantage, then individual } \\
\text { investors will think again on the decisions that have been taken }\end{array}$ \\
\hline 5 & PIP10 & $\begin{array}{l}\text { Individual investors feel confrontational often with fellow } \\
\text { investors or brokers. }\end{array}$ \\
\hline F3 & & \begin{tabular}{l} 
DM BASE ON ACCOUNTING INFORMATION \& ENVIROMENT CONDITION \\
\hline 9
\end{tabular} PIP04 & $\begin{array}{l}\text { Individual investors feel like the work environment to be able to } \\
\text { make a comfortable stock investment transaction. }\end{array}$ \\
\hline 7 & PIP12 & $\begin{array}{l}\text { Individual investors feel the need to know in detail and like to } \\
\text { look at things that exist in the workplace environment or a place } \\
\text { to share transactions. }\end{array}$ \\
\hline 5 & PIP30 & $\begin{array}{l}\text { Individual investors will buy shares because they understand the } \\
\text { accounting information of the shares have a good and profitable } \\
\text { performance in the present or future }\end{array}$ \\
\hline 3 & PIP20 & \begin{tabular}{l} 
Investor individu menyukai perubahan yang mendadak \\
\hline S
\end{tabular} \\
\hline
\end{tabular}

\begin{tabular}{|c|c|l|}
\hline F4 & TECHNICAL ANALYSIS \\
\hline 9 & AT07 & $\begin{array}{l}\text { Investor individu mengerti akan perpotongan garis, dimana MA } \\
20 \text { berada di bawah MA 50, maka keputusannya menjual saham } \\
\text { karena harga akan bergerak turun. }\end{array}$ \\
\hline 7 & AF02 & $\begin{array}{l}\text { Individual investors when choosing shares do not consider the } \\
\text { working capital owned by the company to be purchased. }\end{array}$ \\
\hline 5 & AT09 & $\begin{array}{l}\text { Individual investors see the intersection of lines, where MA 20 is } \\
\text { above MA 50, then the decision to buy shares because prices } \\
\text { move up }\end{array}$ \\
\hline
\end{tabular}

\begin{tabular}{|l|l|l|}
\hline \multicolumn{2}{|l|}{ F5 } & FUNDAMENTAL ANALYSIS \\
\hline 9 & AF06 & $\begin{array}{l}\text { Individual investors see the stock selection tends to see the level } \\
\text { of financial risk in the last 3 years. }\end{array}$ \\
\hline 7 & AF18 & $\begin{array}{l}\text { Individual investors will make the decision to sell shares if the } \\
\text { intrinsic (fair) price is smaller than the market price (overvalued). }\end{array}$ \\
\hline 3 & AF04 & $\begin{array}{l}\text { Individual investors will see the company selected for stock } \\
\text { investment has a smaller proportion of long-term debt than its } \\
\text { equity. } \\
\text { Individual investors will make the decision to buy shares when } \\
\text { they see how much the manager manages the company's } \\
\text { operations to be efficient. }\end{array}$ \\
\hline
\end{tabular}

Source: Sitinjak, et al. (2019)

\subsection{Models}

The results of the AHP model are seen (Table 2), each decision maker prefers to achieve the target in accordance with the planning that has been done. Investors prefer a good relationship with fellow investors. Individual investors will also enjoy a comfortable environment in conducting transactions. Individual investors will also buy if MA 20 is below MA 50, the decision to sell shares because prices will move down. Investors also see the level of financial risk in the last 3 years, if it is risky, it will not buy it for investors who are afraid of risk, and vice versa for investors who like risk but can see the future prospects of the performance that will result if financial risk (long-term liabilities) is used to company expansion going forward.

The decision model is required to be a model of the process of buying, selling, and holding a stock investment. Stages starting from technical analysis information, see historical data formed by closing prices of shares. Then see accounting information from profitability and corporate action taken by the company. The corporate action is in the form of dividends, reverse stock split, and right issues. The final stage of Figure 3 model is the target and accuracy of each information and investment strategy carried out.

The next stage, the model that emerges is the least-square partial analysis. Where, each variable used such as macro information, accounting information, and technical information is made quantitative and has a possible formula as below.

$$
\begin{aligned}
& \mathrm{MI}=\alpha+\beta \mathrm{AI}+\beta_{2} \mathrm{TI}+\varepsilon \ldots \ldots \ldots \\
& \mathrm{BF}=\alpha+\beta \mathrm{AI}+\beta_{2} \mathrm{TI}+\beta_{3} \mathrm{PI}+\varepsilon
\end{aligned}
$$

Where: $\alpha=$ Constant; $\beta=$ Regression Coefficient; $\mathrm{BF}=$ Behavior Finance; $\mathrm{AI}=$ Accounting Information; $\mathrm{TI}=$ Technical Information; PI = Investor Personality; $\varepsilon=$ Error. 


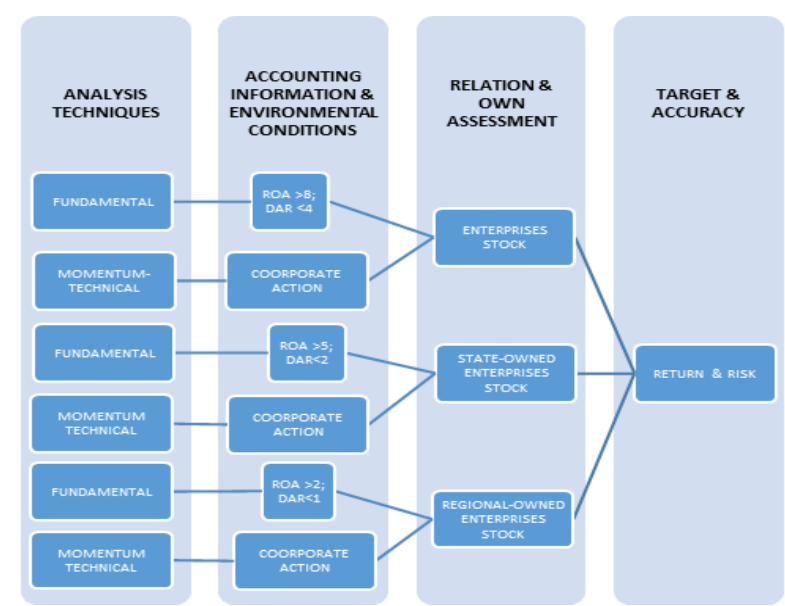

Figure 3. Model of Buying-Selling-Holding Individual Investor (Source: Sitinjak, et al., 2019)

\section{Results}

The results of research for personalities, individual investors in the city of SemarangIndonesia tend to be Precisionist styles (C and $\mathrm{S}$ ). Precisionist styles is a systematic thinker who tends to follow procedures both in personal and business life. Continue in an orderly manner, the way that has been established. Precisionist is precise in paying attention to details. They acted very wisely, diplomatically and were rarely hostile to their colleagues. Being very thorough, precisionists go to great lengths to achieve accuracy in work and maintain high standards. Precisionist tends to get caught up in details, especially when decisions must be made. They want a standard operating procedure and there are no sudden changes.

As a Precisionist, they like a protected and safe environment that is governed by rules and regulations. A precisionist likes people, but prefers some close friends to be recognized. Precisionist prefers small groups to many people. They will use most of their time to ascertain how precisely they are. Precisionist is too sensitive and might not handle criticism well. They need to develop self-confidence and be more independent. They tend to worry a little about what people think of them and they avoid conflict and change at all costs.

Being precise is very important in all respects for precisionists. They can be relied upon to carry out any task correctly. They want the real facts and figures before they will make a decision. They will feel uncomfortable when forced to make quick decisions. Precisionist will often maintain feelings for themselves. Others may not realize that they have strong beliefs. Precisionist will not explode easily when depressed or stressed, but is likely to withdraw. They want a stable home and work environment that promotes security. The more stable, organized and non-confrontational the environment, the happier it will be.

The results of the FGDs are three things that are often mentioned, namely, first, macro information is not often used in stock transactions. There are three types of investors, fundamental investors, technical investors, and mix of fundamental and technical investors (hybrid investors). The second discovery in the FGD is that individual investors will form their own investment strategies in the third year. If you remain an investor in the third year, he will reduce his anxiety and doubts when making a stock transaction. The third determination in the FGD, that investors are more inclined to homo sapiens than homo economicus, if there is a crisis occurs or a huge loss, then only investor relations with Him (the Creator of the Universe) can provide power and enlightenment in stock investment transactions.

Qualitative results are made quantitative, then the individual investor behaviour model shows the investor's personality that forms the pattern of the transaction strategy. Market information is more absorbed in accounting and technical information. When confronted 
directly with the latent variable macro information on financial behaviour, it has no effect (figure 2). Unlike the second model, macro information affects accounting information and technical information, not directly to the financial behaviour of individual investors.

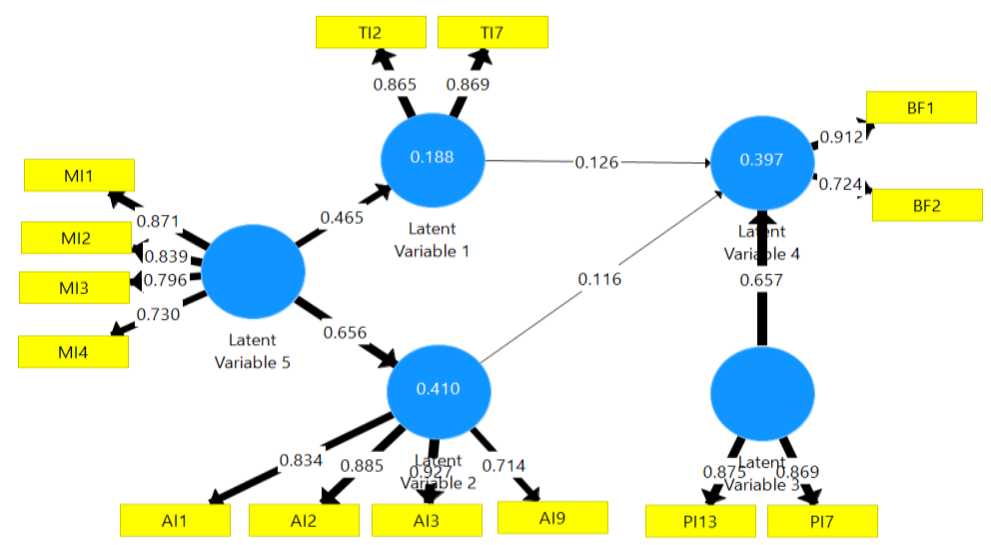

Figure 4. Model Behavioural Finance Information (Source: Data processed, 2019)

\section{Discussion}

Analysis of the results obtained is the financial behavior of investors in a pattern of 3 things, first, the target pattern of yields and the risk of the shares they buy, sell and hold both from the learning stage to becoming an actual investor (1-2 years with various the strategy used, the 3rd year the choice is crucial is whether or not to become a stock investor). Second, the social patterns of individual investors in making decisions both in daily life and life on campus or in the office. This makes self-assessment of individual investors will be different in choosing the shares to be invested. Third, the pattern of investor environmental care about the environment. This affects the selection of stocks that care about the environment.

The behavior of individual investors in the Indonesian Capital Market tends to be irrational which is still controlled with positive emotions. Positive emotions here, emotions that can provide impetus provide positive decisions. If you experience losses you will not immediately cut-loss and buy with the average down method. However, the behavior that is often shown is wait and see, hold shares with hold to long until finally getting a profit (Kahneman \& Tversky, 1979; Maretha, 2013; Maretha, et al. 2016), the shares will be sold. The results of fundamental analysis for this study are also supported by the results of umbrella research with students. The result is that non-bank BUMN companies are better in liquidity ratios (Current Ratio and Working Capital Ratio) and profitability (Return on Equity and Return on Assets) at the introduction, shake and mature business cycle stages. Whereas the non-bank BUMD ratio influential companies are leverage ratio (Debt to Equity Ratio, Debt to Asset Ratio) and activity ratio (Total Asset Turn Over) at the growth stage. Listed companies have better private company ratios in liquidity ratios (Quick Ratio, Loan to Deposit Ratio, Loan to Acid Ratio) and profitability (Net Profit Margin and Return on Assets) at the introduction and mature business cycle stages. The results of this study are fundamentally also supported by umbrella research, namely the financial ratios that influence when the business cycle is at the introduction of liquidity ratio (Current Ratio), the growth ratio of leverage ratio (Debt to EBITDA Ratio), liquidity ratio shake stage (Current Ration) and leverage ratio (Debt to EBITDA Ratio), the mature stage plays a profitability ratio (Return on Equity), a stage of decline that plays a ratio of leverage, liquidity, and activity (Total Assets Turn Over). The business cycle in umbrella research uses operational cash flow, investment and funding (Pradipta, et al, 2019). The results support the results of the fundamental analysis of the next umbrella research showing accounting profits play more 
influence in the return on stock investment than the amount of free cash flow (FCF) (Listyawati, et al, 2019). Free cash flow (FCF) is a flow of funds that can be used in addition to the company's operational and investment expenses.

\section{Conclusion}

Individual investors have a target in investing in shares. Individual investors also have the accuracy of information that individual investors absorb. Macro information goes into technical and fundamental information, so individual investors are more likely to use their personalities in forming stock investment strategies. Individual investors in Indonesia tend to have precisionist styles (a combination of Compliance and Steadiness,). Precisionist styles is a systematic thinker who tends to follow procedures both in personal and business life. Investor behaviour towards emotions, anxiety, and euphoria will be more manageable when individual investors step into the third year as investors. This is formed in investors from a mixture of personality and learning while buying, selling and holding stock investments.

\section{Acknowledgment}

This paper is an output of the science project Fundamental Research Grants from the RISTEK DIKTI-Indonesia (Funding in 2019).

\section{References}

Baddeley. (2012). Working Memory: Theories, Models, and Controversies. Annual Review of Psychology, Vol. 63, pp. 1-29.

Byrne \& Brooks. (2008). Behavioral Finance: Theories and Evidence. The Research Foundation of CFA Institute Literature Review.

Kadariya. (2012). Factors affecting investor decision making: A case of Nepalese capital market. Journal of Research in Economics and International Finance, vol. 1, no.1.

Lipe, M. G. (1998). "Individual Investors' Risk Judgments and Investment Decisions: The Impact of Accounting and Market Data." Accounting, Organization, and Society, Vol 23, No. 7, pp. 625-640.

Maretha, E.L, K. Haryanti, \& Y. W. Sasmito. (2016). Perilaku Investor Individu berdasarkan Portofoio dan DISC-Personality di Pasar Modal Indonesia. Proceedings of Nasional Conference APMMI-Disruptive Innovation. Malang, Indonesia, pp. 119-129.

Maretha, E.L. (2013). Perilaku Investor Individu dalam Pembuatan Keputusan Investasi Saham: Efek Disposisi dan Informasi Akuntansi. Jurnal Organisasi dan Manajemen, vol.9. no.1 Maret, pp. 31-53.

Natapura, C. (2009). "Analisis Perilaku Investor Institusional dengan Pendekatan Analytical Hierarchy Process (AHP)". Jurnal Ilmu Administrasi dan Organisasi, Sept-Des, Vol.16, No.3. pp. 180-187.

Saaty, R. W. (1987). "The Analytic Hierarchy Process-What it is and How it is Used," Mathl Modelling, vol. 9, no. 3-5, pp. 161-176.

Septyanto (2013). Faktor-Faktor yang mempengaruhi Investor Indvidu dalam PengambilanKeputusan Investasi Sekuritas di Bursa Efek Indonesia (BEI). Jurnal Ekonomi, Vol. 4 No.2.

Sitinjak, E. L. M., K. Haryanti, W. Kurniasari, and Y.W. D. Sasmito (2019). Investor Behavior Based on Personality and Company Life Cycle, Holistica, vol. 10, issue 2, pp. 493-499. 


\section{Appendixs}

\begin{tabular}{|c|c|c|c|c|c|}
\hline & \multicolumn{5}{|c|}{$\underset{\text { sex }}{\text { Demograpy Responden }}$} \\
\hline & & Frequency & Percent & Valid Percent & $\begin{array}{c}\text { Cumulative } \\
\text { Percent }\end{array}$ \\
\hline \multirow[t]{3}{*}{ Valid } & Man & 22 & 73.3 & 73.3 & 73.3 \\
\hline & Women & 8 & 26.7 & 26.7 & 100.0 \\
\hline & Total & 30 & 100.0 & 100.0 & \\
\hline
\end{tabular}

\begin{tabular}{|c|c|c|c|c|c|}
\hline \multicolumn{6}{|c|}{ transaction } \\
\hline & & Frequency & Percent & Valid Percent & $\begin{array}{c}\text { Cumulative } \\
\text { Percent }\end{array}$ \\
\hline \multirow[t]{5}{*}{ Valid } & $1-2$ & 22 & 73.3 & 73.3 & 73.3 \\
\hline & 3-4 & 1 & 3.3 & 3.3 & 76.7 \\
\hline & $5-6$ & 5 & 16.7 & 16.7 & 93.3 \\
\hline & $>=7$ & 2 & 6.7 & 6.7 & 100.0 \\
\hline & Total & 30 & 100.0 & 100.0 & \\
\hline
\end{tabular}

\begin{tabular}{|c|c|c|c|c|c|}
\hline & & Frequency & Percent & Valid Percent & $\begin{array}{c}\text { Cumulative } \\
\text { Percent }\end{array}$ \\
\hline \multirow[t]{8}{*}{ Valid } & 19 & 1 & 3.3 & 3.3 & 3.3 \\
\hline & 21 & 17 & 56.7 & 56.7 & 60.0 \\
\hline & 22 & 5 & 16.7 & 16.7 & 76.7 \\
\hline & 23 & 4 & 13.3 & 13.3 & 90.0 \\
\hline & 36 & 1 & 3.3 & 3.3 & 93.3 \\
\hline & 44 & 1 & 3.3 & 3.3 & 96.7 \\
\hline & 61 & 1 & 3.3 & 3.3 & 100.0 \\
\hline & Total & 30 & 100.0 & 100.0 & \\
\hline
\end{tabular}

\section{Descriptive Statistics Market Information}

\begin{tabular}{|l|r|r|r|r|r|}
\hline & \multicolumn{1}{|c|}{ N } & Minimum & Maximum & Mean & Std. Deviation \\
\hline M11 & 30 & 1 & 5 & 3.70 & 1.022 \\
M12 & 30 & 1 & 5 & 3.47 & 1.008 \\
M13 & 30 & 2 & 5 & 3.70 & 1.022 \\
M14 & 30 & 2 & 5 & 3.67 & .994 \\
M15 & 30 & 3 & 5 & 4.23 & .728 \\
Valid N (listwise) & 30 & & & & \\
\hline
\end{tabular}

Source: Data processed (2019)
Reliability Data

\begin{tabular}{|c|r|}
\hline $\begin{array}{c}\text { Cronbach's } \\
\text { Alpha }\end{array}$ & N of Items \\
\hline .785 & 33 \\
\hline
\end{tabular}

Descriptive Statistics Accounting Information

\begin{tabular}{|l|r|r|r|r|r|}
\hline & N & Minimum & Maximum & Mean & Std. Deviation \\
\hline A11 & 30 & 3 & 5 & 4.13 & .629 \\
A2 & 30 & 1 & 5 & 4.07 & .907 \\
A13 & 30 & 2 & 5 & 4.17 & .747 \\
A14 & 30 & 2 & 5 & 4.23 & .817 \\
A15 & 30 & 2 & 5 & 3.83 & .791 \\
AA7 & 30 & 2 & 5 & 3.73 & .828 \\
A18 & 30 & 2 & 5 & 4.17 & .874 \\
A19 & 30 & 1 & 5 & 3.93 & .907 \\
Al10 & 30 & 1 & 5 & 3.53 & 1.224 \\
Valid N (listwise) & 30 & & & & \\
\hline
\end{tabular}

Descriptive Statistics Technical Information

\begin{tabular}{|l|r|r|r|r|r|}
\hline & \multicolumn{1}{|c|}{ N } & Minimum & Maximum & Mean & Std. Deviation \\
\hline T12 & 30 & 1 & 4 & 2.33 & 1.028 \\
T14 & 30 & 1 & 5 & 2.77 & 1.406 \\
T15 & 30 & 1 & 5 & 3.53 & 1.042 \\
T16 & 30 & 1 & 5 & 3.30 & .952 \\
T17 & 30 & 1 & 5 & 2.77 & 1.223 \\
Valid N (listwise) & 30 & & & & \\
\hline
\end{tabular}

Descriptive Statistics Personality Information

\begin{tabular}{|c|c|c|c|c|c|}
\hline & $\mathrm{N}$ & Minimum & Maximum & Mean & Std. Deviation \\
\hline P11 & 30 & 1 & 5 & 3.17 & $\begin{array}{l}1.147 \\
\end{array}$ \\
\hline $\mathrm{P} 14$ & 30 & 2 & 5 & 4.17 & 913 \\
\hline P15 & 30 & 1 & 5 & 3.13 & 1.137 \\
\hline P16 & 30 & 1 & 5 & 3.53 & 1.167 \\
\hline P17 & 30 & 1 & 5 & 2.30 & 1.022 \\
\hline P18 & 30 & 1 & 5 & 2.47 & 1.042 \\
\hline P111 & 30 & 2 & 5 & 4.13 & .629 \\
\hline $\mathrm{Pl12}$ & 30 & $2^{2}$ & 5 & 4.00 & .695 \\
\hline & 30 & 1 & 5 & 2.70 & 1.343 \\
\hline Valid N (listwise) & 30 & & & & \\
\hline
\end{tabular}

